\title{
How representative are subfossil assemblages of Chironomidae and common benthic invertebrates for the living fauna of Lake De Waay, the Netherlands?
}

\author{
M. van Hardenbroek • O. Heiri • M. F. Wilhelm • \\ A. F. Lotter
}

Received: 18 June 2010/Accepted: 29 October 2010/Published online: 24 November 2010

(C) The Author(s) 2010. This article is published with open access at Springerlink.com

\begin{abstract}
The distribution of benthic invertebrates and their subfossil remains was examined within the basin of De Waay, a dimictic, eutrophic lake in the Netherlands. We focused on Chironomidae, but also report the abundances of 11 invertebrate groups that potentially produce chitinous remains that are preserved in the fossil record, although their remains could only be identified at a coarser taxonomic resolution. Most living invertebrates sampled in different seasons were constrained to the littoral zone, with the exception of a few taxa (Ceratopogonidae, Chaoborus flavicans, and Chironomus) that are adapted to low oxygen conditions in the seasonally anoxic profundal zone. In contrast, assemblages of invertebrate remains in lake surface sediments were similar in the entire lake basin, suggesting that considerable numbers of invertebrate remains are transported and redeposited off-shore in Lake De Waay, due to its steep bathymetry. These results indicate that a single sediment sample obtained from the centre of this lake contains subfossil invertebrate remains originating from the entire lake basin. In Lake De Waay, the majority of taxa found in the living assemblages were
\end{abstract}

M. van Hardenbroek $(\bowtie) \cdot$ O. Heiri · A. F. Lotter

Laboratory of Palaeobotany and Palynology,

Institute of Environmental Biology, Palaeoecology,

Utrecht University, Budapestlaan 4, 3584 CD Utrecht,

The Netherlands

e-mail: m.r.vanhardenbroek@uu.nl

O. Heiri

Institute of Plant Sciences and Oeschger Centre for Climate

Change Research, University of Bern, Altenbergrain 21,

3013 Bern, CH, Switzerland

M. F. Wilhelm

Grontmij, team Ecology (AquaSense), Science Park 116,

1090 HC Amsterdam, The Netherlands identified as remains in lake surface sediments, at least for the Chironomidae that could be identified at a similar taxonomic level in living and subfossil assemblages. Of the total 44 chironomid taxa found in Lake De Waay, 35 taxa occurred in the living assemblages and 34 taxa occurred in the subfossil assemblages. Thirty chironomid taxa occurred both as living and subfossil specimens, and on average these 30 taxa represent $94 \%$ of the specimens encountered in a sediment sample. Five rare chironomid taxa present as living larvae were not detected in the subfossil assemblages. Conversely, eight rare and four common chironomid taxa were found in subfossil remains, but not in living assemblages. Our results indicate that subfossil assemblages in surface sediment samples provide spatially integrated and representative samples of the living assemblage. However, a combined approach examining both the living benthic invertebrate fauna and invertebrate remains in lake surface sediments will potentially give a more complete and detailed overview of benthic invertebrates in a lake ecosystem than an approach based exclusively on one of these groups.

Keywords Invertebrates - Chironomids - Assemblages · Taphonomy $\cdot$ Redistribution

\section{Introduction}

Invertebrates are ubiquitous in lakes and their remains are preserved in lake sediments. Several groups of aquatic invertebrates have been shown to be sensitive to changes in their environment (Frey 1964; Smol et al. 2001) and are, therefore, often used as indicators in biomonitoring studies (Rosenberg and Resh 1993; Free et al. 2009). Not only is the living community indicative of the present state of 
lakes, but fossil invertebrate assemblages can also provide information about past changes in lake ecosystems (Frey 1964; Rumes et al. 2005). In addition, the analysis of subfossil invertebrate assemblages in lake surface sediments has potential to be used in biomonitoring, either as a quick screening tool to identify lakes with unusual invertebrate assemblages or as a supplementary method to be used together with sampling of living invertebrates. Lake surface sediments provide spatially and temporally integrated samples (Frey 1988) and, depending on the sedimentation rate, the top $\mathrm{cm}$ of sediment may represent several seasons to years of deposited material. Since material is usually transported from shallower sections of lakes towards the deepest parts, sediments obtained from the lake centre will typically include invertebrate remains originating from the entire lake basin, at least in small lakes (Smol 2008).

Several aquatic invertebrate groups have been used in palaeoenvironmental studies (Smol et al. 2001). Of these groups, the chironomids are one of the most abundant benthic macroinvertebrate groups in aquatic ecosystems (Pinder 1995) and have increasingly attracted attention in palaeolimnology over the past two decades. Their larval head capsules often occur in high abundances in sediments and have been used to reconstruct a range of environmental variables such as temperature (Heiri et al. 2007; Ilyashuk et al. 2009), lake trophic status (Lotter et al. 1998; Langdon et al. 2006), water depth (Korhola et al. 2000; Kurek and Cwynar 2009a), and oxygen availability (Quinlan and Smol 2001a; Heiri and Lotter 2003; Verbruggen et al. 2010).

In many palaeolimnological studies, one sediment core is used to reconstruct past environmental changes for the entire lake system. This approach involves a number of assumptions about how well the subfossil assemblage represents the living community. Good agreement between living and subfossil assemblages have been observed for a number of palaeoecological indicator groups, including, e.g., Chaoborus (Quinlan and Smol 2010), Chironomidae (Iovino 1975), and Cladocera (Kattel et al. 2007). Several biotic and abiotic factors can influence the within-lake distribution of subfossil assemblages. Temporal and spatial variation in the living assemblages may result from specific habitat preferences (Frey 1988; Hofmann 1988; Moog 2002). Later, diagenetic processes and transport may affect certain taxa more strongly than others (Walker et al. 1984; Frey 1988; Brodersen and Lindegaard 1999; Eggermont et al. 2007). For chironomids, it has been shown that different subfossil assemblages can be found in different locations within a lake basin (Schmäh 1993; Heiri 2004; Eggermont et al. 2007; Kurek and Cwynar 2009a, b).

In this study, we examined to what extent subfossil remains of common invertebrate groups in a small, stratified Dutch lake accurately represent living communities. We focused on aquatic invertebrates with subfossil chitinous remains that were retained in a $100 \mu \mathrm{m}$-mesh sieve. These included several groups of Diptera (especially chironomids), Bryozoa, Coleoptera, and Oribatida. Subfossil assemblages in surface sediments were compared with living specimens that were collected in the same lake. Information on how well subfossil assemblages represent the living community is vital to accurately interpret downcore palaeolimnological records and to compare assessments based on lake surface sediments with other biomonitoring methods (Sayer et al. 2010).

\section{Methods}

Surface sediments and samples of living invertebrates were obtained from Lake De Waay, a hypertrophic hardwater lake in the Netherlands with a maximum water depth of $15 \mathrm{~m}$ and a surface area of 1.3 ha (see Fig. 1; Table 1 for location and general characteristics). The lake is a scour hole that was formed by a dike breach in $1496 \mathrm{AD}$
Fig. 1 a Location of Lake De Waay in the Netherlands, and b bathymetry of the basin and location of the sediment samples along a transect $\left(\mathrm{A}-\mathrm{A}^{\prime}\right)$ from the littoral to the profundal. Grey circles indicate sampling stations along the transect and grey squares indicate locations of additional kick net samples
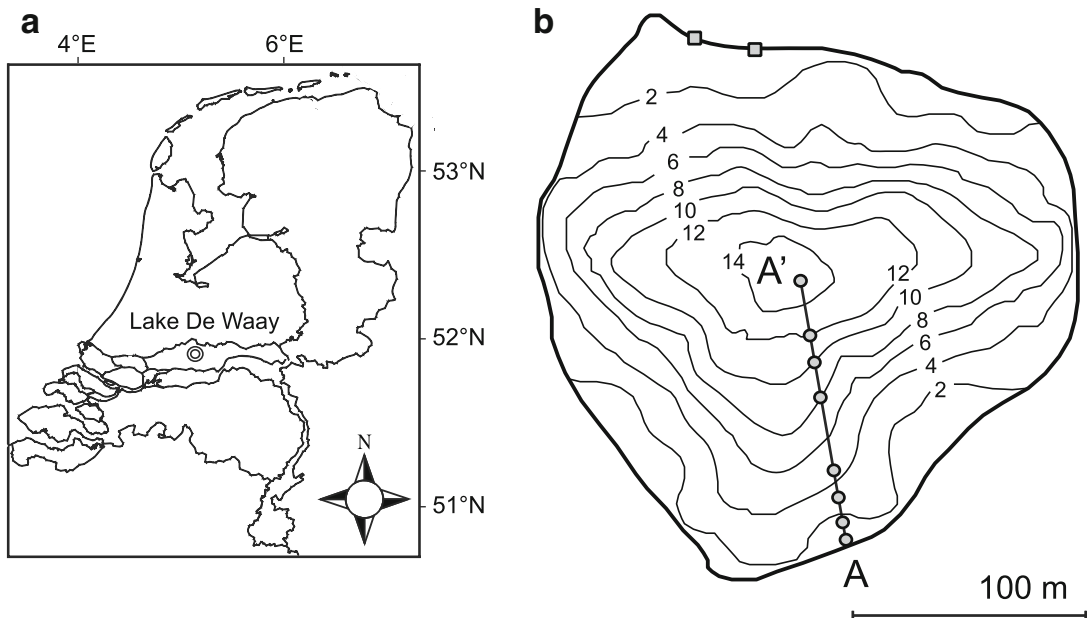
Table 1 Physical characteristics and water chemistry of Lake De Waay

\begin{tabular}{ll}
\hline Location & $51^{\circ} 55^{\prime} 55^{\prime \prime} \mathrm{N} / 5^{\circ} 8^{\prime} 59^{\prime \prime} \mathrm{E}$ \\
Area (ha) & 1.3 \\
Maximum depth $(\mathrm{m})$ & 15 \\
Secchi Depth $(\mathrm{m})$ & $1.20-2.15(1.43)$ \\
$\mathrm{pH}$ & $7.5-8.6(7.9)$ \\
Conductivity $\left(\mu \mathrm{S} \mathrm{cm}{ }^{-1}\right.$ at $\left.25^{\circ} \mathrm{C}\right)$ & $441-544(474)$ \\
Total P $\left(\mu \mathrm{g} \mathrm{L}^{-1}\right)$ & $105-119(112)$ \\
Total N (mg L & $1.17-2.08(1.82)$ \\
Dissolved organic carbon $\left(\mu \mathrm{mol} \mathrm{L}^{-1}\right)$ & $468-553(493)$
\end{tabular}

The range of measured values $(n=3)$ is indicated and average values are given in parentheses

(Kirilova et al. 2010) and is partly surrounded by dykes at present. Agriculture, recreational activities, overwintering waterfowl, and local water management in the catchment heavily influence the lake, and sedimentation rates in the central part of the lake basin are high, approximately $2.3 \mathrm{~cm}$ per year (Kirilova et al. 2010). De Waay is a dimictic lake with a seasonally anoxic hypolimnion. The lake is usually stratified from April to October with a thermocline between 3 and $6 \mathrm{~m}$ water depth (Fig. 2, Leentvaar 1958). It could, therefore, be expected that distinct changes in the invertebrate community occur with water depth.

Samples of living invertebrates were collected in 2007-2009 once at the end of summer (13 September 2007), once at the beginning of spring (22 April 2008),

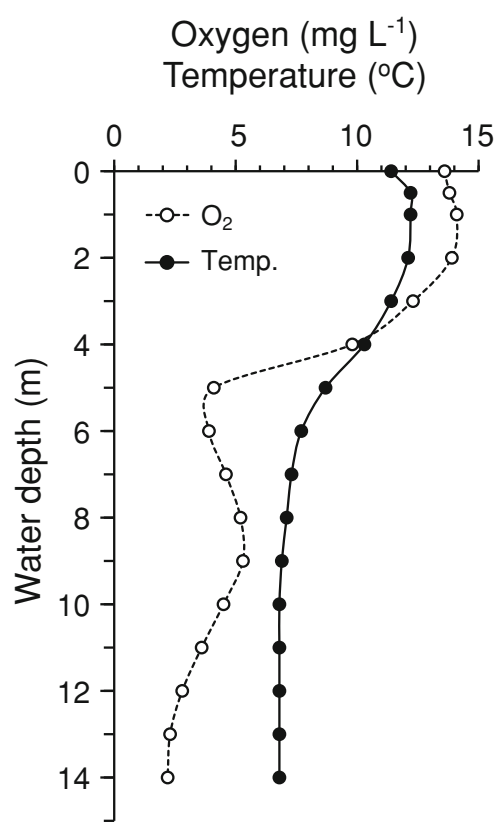

Fig. 2 Oxygen and temperature profiles of Lake De Waay after stratification took place (22 April 2008) and once in winter (17 February 2009). These samples were taken with a $15 \times 15 \times 15 \mathrm{~cm}$ Ekman grab at eight stations along a depth transect and immediately sieved with a $0.5 \mathrm{~mm}$ mesh-size net. A single grab of $3.5 \mathrm{~L}$ of sediment per station was taken from the littoral and sublittoral zones $(<4 \mathrm{~m}$ depth) and double grabs from the profundal ( $>4 \mathrm{~m}$ depth) part of the basin. Additional kick net samples were taken from the shoreline between emerging macrophyte vegetation with a $0.5 \mathrm{~mm}$ net. All invertebrate samples were sorted the day after fieldwork in the laboratory, identified following Grontmij (2010) and then preserved in alcohol. Samples taken at different seasons were pooled at each station along the transect to allow for numerical analysis and plotting, and to include similar time intervals for living assemblages (representing 3 seasons in 1.5 years) and subfossil assemblages (representing ca. 1-2 years in the top $2 \mathrm{~cm}$ of sediment; Kirilova et al. 2010).

Surface sediments for obtaining subfossil invertebrate remains were sampled at the same eight stations along the depth transect with a HTH sediment corer (Renberg and Hansson 2008). Sediment cores were subsampled in the field into $2 \mathrm{~cm}$ slices and only the top $2 \mathrm{~cm}$ slice was used, except at $15 \mathrm{~m}$ water depth where the top $4 \mathrm{~cm}$ was used because of low concentrations of subfossils. Sediments were deflocculated for $2 \mathrm{~h}$ in $10 \% \mathrm{KOH}$ at room temperature and sieved over a $100 \mu \mathrm{m}$ sieve. Subfossil remains were picked out individually using a stereo microscope (25-40 $\times$ magnification) with fine forceps. Between 36 and 72 chironomid head capsules for each sample were identified using a light microscope at 60-600× magnification. Remains of chironomids were identified following Wiederholm (1983), Rieradevall and Brooks (2001) and Brooks et al. (2007). Other invertebrate remains were identified at a coarser taxonomic resolution following Frey (1964), Reusch and Oosterbroek (1997), Vanderkerkhove et al. (2004), Wood and Okamura (2005), and Brooks et al. (2007).

To make the data of living and subfossil assemblages comparable, modern and subfossil taxonomy were harmonized by pooling equivalent taxa in living and subfossil assemblages following Tables 2 and 3. This resulted in a harmonized taxonomy of 47 invertebrate taxa that could be applied to both living and subfossil assemblages. Furthermore, we transformed the data into percentages (Clarke and Warwick 2001). Detrended correspondence analysis (DCA) was performed using the program CANOCO version 4.52 (ter Braak and Šmilauer 2003) to explore patterns in the distribution of invertebrate taxa. DCA was run on the harmonized taxonomy that included 47 invertebrate taxa, with detrending by segments, squareroot-transformation of species abundances and downweighting of rare taxa. 
Table 2 Comparison of chironomid taxa identified in living and subfossil assemblages in Lake De Waay, with references for identification of subfossil remains
Taxa found in living assemblages are aligned with their equivalent subfossil taxa. Taxa that only occur in either living or subfossil assemblages are printed in bold

\begin{tabular}{|c|c|c|}
\hline Living assemblages & Subfossil assemblages & Reference subfossil ID \\
\hline Ablabesmyia longistyla & Ablabesmyia & Rieradevall and Brooks (2001) \\
\hline \multicolumn{3}{|l|}{ Apsectrotanypus trifascipennis } \\
\hline $\begin{array}{l}\text { Chironomus annularius agg } \\
\text { Chironomus commutatus }\end{array}$ & Chironomus anthracinus-type & Brooks et al. (2007) \\
\hline \multirow{2}{*}{$\begin{array}{l}\text { Chironomus muratensis } \\
\text { Chironomus plumosus agg. }\end{array}$} & Chironomus plumosus-type & Brooks et al. (2007) \\
\hline & Cladopelma lateralis-type & Brooks et al. (2007) \\
\hline \multirow[t]{2}{*}{ Cladotanytarsus } & Cladotanytarsus mancus-type1 & Brooks et al. (2007) \\
\hline & Corynoneura edwardsi-type & Brooks et al. (2007) \\
\hline \multirow{2}{*}{$\begin{array}{l}\text { Cricotopus intersectus } \\
\text { Cricotopus intersectus agg. }\end{array}$} & Cricotopus intersectus-type & Brooks et al. (2007) \\
\hline & Cricotopus laricomalis-type & Brooks et al. (2007) \\
\hline Cricotopus sylvestris gr. & Cricotopus sylvestris-type & Brooks et al. (2007) \\
\hline Cryptochironomus & Cryptochironomus & Brooks et al. (2007) \\
\hline \multirow[t]{2}{*}{ Dicrotendipes nervosus } & Dicrotendipes nervosus-type & Brooks et al. (2007) \\
\hline & Dicrotendipes notatus-type & Brooks et al. (2007) \\
\hline \multirow[t]{2}{*}{ Endochironomus albipennis } & Endochironomus albipennis-type & Brooks et al. (2007) \\
\hline & Endochironomus tendens-type & Brooks et al. (2007) \\
\hline Glyptotendipes paripes & Glyptotendipes barbipes-type & Brooks et al. (2007) \\
\hline \multirow[t]{4}{*}{ Glyptotendipes pallens agg. } & Glyptotendipes pallens-type & Brooks et al. (2007) \\
\hline & Kiefferulus & Wiederholm (1983) \\
\hline & Limnophyes & Brooks et al. (2007) \\
\hline & Metriocnemus eurynotus-type & Brooks et al. (2007) \\
\hline \multirow{2}{*}{$\begin{array}{l}\text { Microtendipes chloris } \\
\text { Microtendipes chloris gr. }\end{array}$} & Microtendipes pedellus-type & Brooks et al. (2007) \\
\hline & Microtendipes rydalensis-type & Brooks et al. (2007) \\
\hline Nanocladius bicolor agg. & Nanocladius rectinervis & Brooks et al. (2007) \\
\hline \multirow{2}{*}{$\begin{array}{l}\text { Parachironomus arcuatus } \\
\text { Parachironomus arcuatus gr. }\end{array}$} & Parachironomus varus & Brooks et al. (2007) \\
\hline & Paramerina & Rieradevall and Brooks (2001) \\
\hline \multirow[t]{2}{*}{ Phaenopsectra } & Phaenopsectra type A & Brooks et al. (2007) \\
\hline & Phaenopsectra flavipes-type & Brooks et al. (2007) \\
\hline Polypedilum nubeculosum & Polypedilum nubeculosum-type & Brooks et al. (2007) \\
\hline Polypedilum sordens & Polypedilum sordens-type & Brooks et al. (2007) \\
\hline \multirow[t]{2}{*}{ Procladius (Holotanypus) } & Procladius & Rieradevall and Brooks (2001) \\
\hline & Psectrocladius sordidellus-type & Brooks et al. (2007) \\
\hline
\end{tabular}

Stictochironomus

Tanypus kraatzi

Tanypus vilipennis

Tanytarsus eminulus gr.

Tanytarsus excavatus

Tanytarsus excavatus gr.

Tanytarsus lestagei agg.

Tanytarsus mendax

Tanytarsus mendax $g r$.

Tanytarsus mendax/occultus

Tanytarsus mendax-type

Brooks et al. (2007)

Tanytarsus pallidicornis-type

Tribelos

Xenochironomus xenolabis
Brooks et al. (2007)

Brooks et al. (2007)

Brooks et al. (2007) 
Table 3 Non-chironomid taxa found in the living and subfossil assemblages of Lake De Waay, with references for identification of subfossil remains
Taxa found in the living assemblages are aligned with their equivalent fossil taxon. Taxa that only occur in either living or subfossil assemblages are printed in bold. Taxon names for groups not found in subfossi assemblages are given in parentheses

\begin{tabular}{|c|c|c|}
\hline Living assemblages & Subfossil assemblages & Reference subfossil ID \\
\hline Arrenurus crassicaudatus & \multirow[t]{10}{*}{ Oribatida } & \multirow[t]{17}{*}{ Frey (1964) } \\
\hline Arrenus latus & & \\
\hline Hydrodoma despiciens sen & & \\
\hline Hygrobates lonipalpis & & \\
\hline Limnesia maculata sensu s & & \\
\hline Limnochares aquatica & & \\
\hline Neumania vernalis & & \\
\hline Piona imminuta & & \\
\hline Pionidae & & \\
\hline Unionicola & & \\
\hline Haliplus & \multirow[t]{4}{*}{ (Coleoptera) } & \\
\hline Hyphydrus ovatus & & \\
\hline Noterus clavicornis & & \\
\hline Stenopelmus rufinasus & & \\
\hline Gammarus pulex & \multirow[t]{3}{*}{ (Malacostraca) } & \\
\hline Gammarus tigrinus & & \\
\hline Asellus aquaticus & & \\
\hline Ceratopogonidae & Ceratopogonidae & Brooks et al. (2007) \\
\hline Chaoborus flavicans & Chaoborus spp. & Brooks et al. (2007) \\
\hline \multirow[t]{3}{*}{ (Bryozoa) } & Cristatella mucedo & \multirow[t]{3}{*}{ Wood and Okamura (2005) } \\
\hline & Plumatella spp. & \\
\hline & Lophopus crystallinus & \\
\hline \multirow[t]{2}{*}{ (Daphniidae) } & Ceriodaphnia & \multirow[t]{2}{*}{ Vanderkerkhove et al. (2004) } \\
\hline & Daphnia & \\
\hline (Limoniidae) & Limoniidae & Reusch and Oosterbroek (1997) \\
\hline Caenis horaria & \multirow[t]{5}{*}{ Ephemeroptera } & \multirow[t]{17}{*}{ Brooks et al. (2007) } \\
\hline Caenis luctuosa & & \\
\hline Caenis robusta & & \\
\hline Cloeon dipterum & & \\
\hline Cloeon simile & & \\
\hline Callicorixa praeusta & \multirow[t]{8}{*}{ (Heteroptera) } & \\
\hline Hesperocorixa linnaei & & \\
\hline Huydrometra stagnorum & & \\
\hline Micronecta & & \\
\hline Notonecta glauca & & \\
\hline Sigara falleni & & \\
\hline Sigara lateralis & & \\
\hline Sigara striata & & \\
\hline Aeshna mixta & \multirow[t]{4}{*}{ (Odonata) } & \\
\hline Coenagrionidae & & \\
\hline Ishmura elegans & & \\
\hline Zygoptera & & \\
\hline Anabolia nervosa & \multirow[t]{13}{*}{ Trichoptera } & \multirow[t]{13}{*}{ Frey (1964) } \\
\hline Cyrnus flavidus & & \\
\hline Cyrnus trimaculatus & & \\
\hline Ecnomus tenellus & & \\
\hline Limnephilidae & & \\
\hline Lype раеора & & \\
\hline Molanna angustata & & \\
\hline Mystacides nigra & & \\
\hline Oecetis furva & & \\
\hline Orhotrichia costalis & & \\
\hline Polycentropodidae & & \\
\hline Tinodes waeneri & & \\
\hline Triaenodes bicolor & & \\
\hline
\end{tabular}




\section{Results}

Occurrence of taxa in Lake De Waay

A total of 101 invertebrate taxa were identified in Lake De Waay, 84 taxa in the living assemblages and 45 taxa in the subfossil assemblages (Tables 2, 3). A number of invertebrate taxa was exclusively encountered in the living assemblages (24 taxa) or in the subfossil assemblages (18 taxa). The number of chironomid taxa found in the living assemblages (35 taxa) and in the subfossil assemblages (34 taxa) was similar. In Table 2, we compare corresponding chironomid taxa in living and subfossil assemblages. Of the total 44 chironomid taxa found in Lake De Waay, 30 taxa occurred both as living and subfossil specimens. On average, these 30 taxa represented $94 \%(\mathrm{SD}=7.1 \%)$ of the specimens encountered in a sediment sample.

Five rare chironomid taxa, occurring once in the living assemblages, were not found as subfossils (Apsectrotanypus trifascipennis, Stictochironomus, Tanypus kraatzi, Tanypus vilipennis, and Tanytarsus eminulus gr.). Eight rare chironomid taxa, occurring once or twice in the subfossil assemblages, were not found as living organisms (Cladopelma laterialis-type, Dicrotendipes notatus-type, Kiefferulus, Metriocnemus eurynotus-type, Microtendipes rydalensis-type, Paramerina, Psectrocladius sordidellustype, Tanytarsus pallidicornis-type, and Xenochironomus xenolabis). Also, four common chironomid taxa in subfossil assemblages (Corynoneura edwardsi-type, Endochironomus tendens-type, Limnophyes, and Tanytarsus pallidicornis-type) were not found as living organisms. Living invertebrates were only sampled in the sediment and no epiphytic or planktonic samples were taken.
Therefore, we did not include any Daphniidae or Bryozoa in the live assemblages, although their resting stages were encountered in subfossil assemblages. Taxonomic resolution of non-chironomid invertebrate remains was much coarser than that of chironomid head capsules and several invertebrate taxa found in living assemblages (Coleoptera, Heteroptera, Malacostraca, and Odonata) were not recognized in subfossil assemblages.

Distribution of taxa along a depth transect and DCA

The highest concentrations of living invertebrates $(2,963$ individuals $\mathrm{m}^{-2}$ ) were found in the sample at $0.8 \mathrm{~m}$ water depth, and abundances decreased with depth (Figs. 3, 5). The only taxa found in the deepest part were larvae of Chironomus annularius at 8 and $10 \mathrm{~m}$ water depth, Ceratopogonidae at 10 and $12 \mathrm{~m}$ water depth, and Chaoborus flavicans larvae that were present at high absolute abundances (ca. 350-1,600 larvae $\mathrm{m}^{-2}$ ) in samples taken at $8 \mathrm{~m}$ water depth and below. Subfossil assemblages were similar in samples from different water depth (Figs. 4, 5) and the highest concentrations of subfossil invertebrate remains were found at $4.5 \mathrm{~m}$ water depth (95 remains $\mathrm{g}^{-1}$ dry sediment).

These patterns are apparent in the DCA, which was run using the harmonized invertebrate taxonomy (Fig. 6). The first and second DCA axes accounted for 30.6 and $9.5 \%$ of the variance within the faunal data, respectively. The samples of living assemblages showed a range of 4.3 and 1.4 standard deviation units along Axis 1 and 2, respectively, and the samples of subfossil assemblages showed a range of 0.4 and 0.3 , respectively. In general, the nine samples of living assemblages were arranged along axis 1 according to water depth, the deepest sample at $15 \mathrm{~m}$ being most different

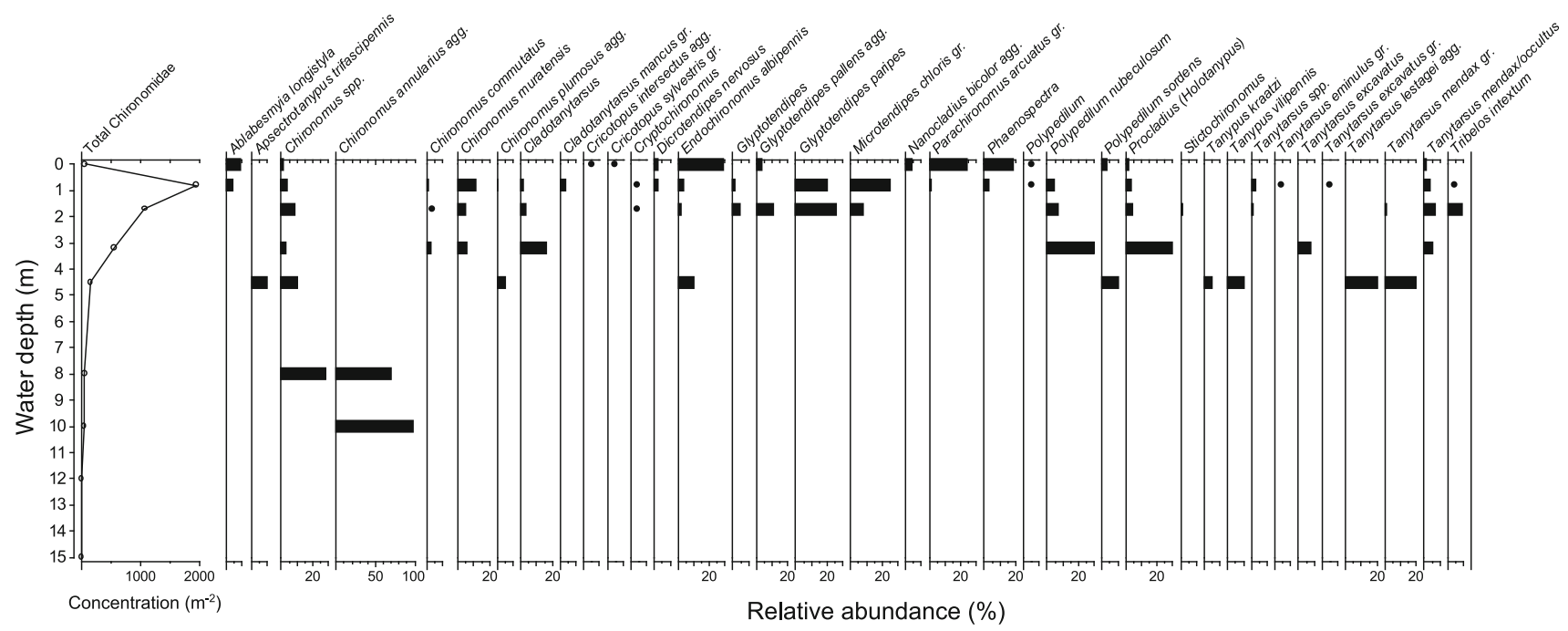

Fig. 3 Relative abundances of living chironomid larvae in Lake De Waay at different water depths. All taxa are plotted, and low abundances $(<1 \%)$ are indicated by black dots. Maximum values of the $\mathrm{x}$-axes are $10 \%$ unless labeled otherwise. The values are averages of three sampling campaigns (13 September 2007, 22 April 2008 and 17 February 2009) 


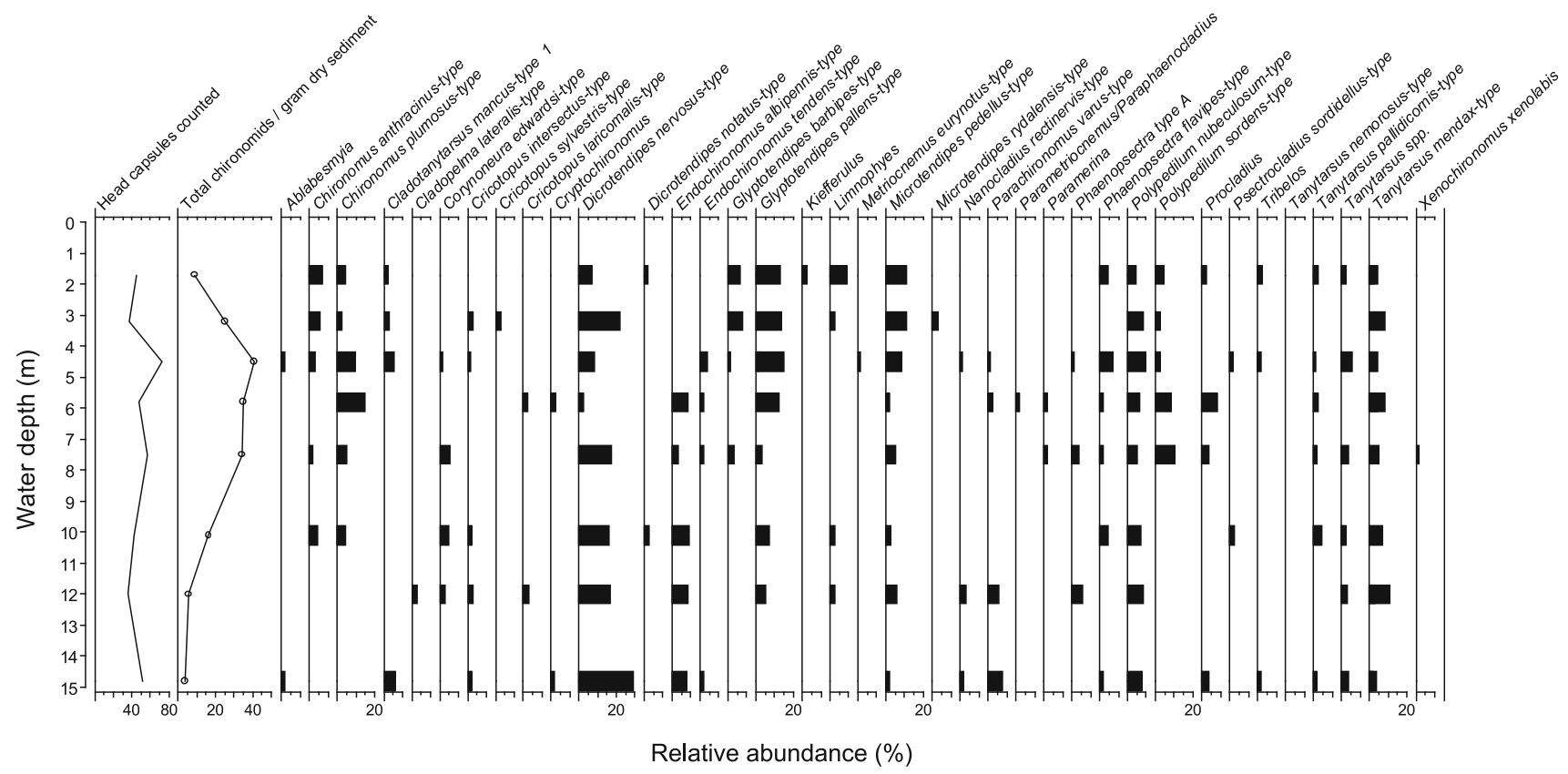

Fig. 4 Total number of chironomid head capsules per gram sediment and relative abundance of all identified subfossil remains in the sediments of Lake De Waay at different water depths. Maximum values of $\mathrm{x}$-axes are $10 \%$ unless labeled otherwise

from the shoreline sample at $0 \mathrm{~m}$. The eight samples with subfossil assemblages on the other hand were remarkably similar in the ordination plot and no clear depth-related pattern was observed in the invertebrate assemblages of these samples. The DCA sample scores indicated that the difference between living and subfossil assemblages became larger with increasing water depth as the subfossil assemblages were most similar to the living assemblages collected in the littoral zone between 0.8 and $3.2 \mathrm{~m}$ water depth.

Chaoborus flavicans was characterized by the lowest DCA axis 1 scores followed by Ceratopogonidae, Chironomus anthracinus-type, and Chironomus spp. (Fig. 6) and these taxa plotted relatively close to samples taken at $8 \mathrm{~m}$ water depth and below. Most taxa of Chironomidae, Coleoptera, Oribatida, Ephemeroptera, and the remains of Daphniidae and Plumatella were characterized by higher DCA axis 1 scores and plotted close to the sample of the living assemblage at 0-3.2 $\mathrm{m}$ water depth in the DCA plot. Other invertebrate groups, including Heteroptera, Limoniidae, Malacostraca, Odonata, Trichoptera, and the remains of Cristatella mucedo and Lophopus crystallinus plotted close to samples of living assemblages from the shallowest samples $(0-1.7 \mathrm{~m})$ in the DCA plot.

\section{Discussion}

Occurrence of taxa in Lake De Waay

Overall, the taxonomic composition of the living and subfossil invertebrate assemblages in Lake De Waay was similar, at least for chironomids that could be identified at a comparable taxonomic level in living and subfossil assemblages. However, a number differences existed between living and subfossil assemblages because some taxa were exclusively encountered as living animals or as subfossil remains. There are a number of potential reasons for these differences that we will discuss here.

Remains that are thin and easily damaged or broken may cause an underrepresentation compared with living invertebrates. For example, Walker et al. (1984) suggested that Procladius may be poorly preserved in some lake sediments. However, in our study, remains of Procladius are common in both living and subfossil assemblages (Fig. 7) and other tanypodine chironomid taxa that produce thin remains are either present in both living and subfossil assemblages (Ablabesmyia), or have only a single occurrence in the living assemblages (Apsectrotanypus).

Taxa occurring in low numbers in Lake de Waay, such as Coleoptera, and the chironomid tribes Orthocladiinae and Tanypodinae, may have been missed due to limited sampling. For example, of the six taxa of Tanypodinae found as living larvae only three (Ablabesmyia, Paramerina, and Procladius) were represented as subfossils. Conversely, of the eight taxa of Orthocladiinae found as subfossils, only Nanocladius and three taxa in the genus Cricotopus were found as living larvae (Table 2). However, the number of living invertebrates found at each sampling station was high (49-1,173, with the exception of 23 specimens at $4.5 \mathrm{~m}$ water depth), and the number of identified chironomid head capsules (36-72) from subfossil 
Fig. 5 Comparison between concentrations of all living invertebrates and their remains identified in Lake De Waay at different water depths. The values for living larvae are averages of three sampling campaigns on 13 September 2007, 22 April 2008, 17 February 2009

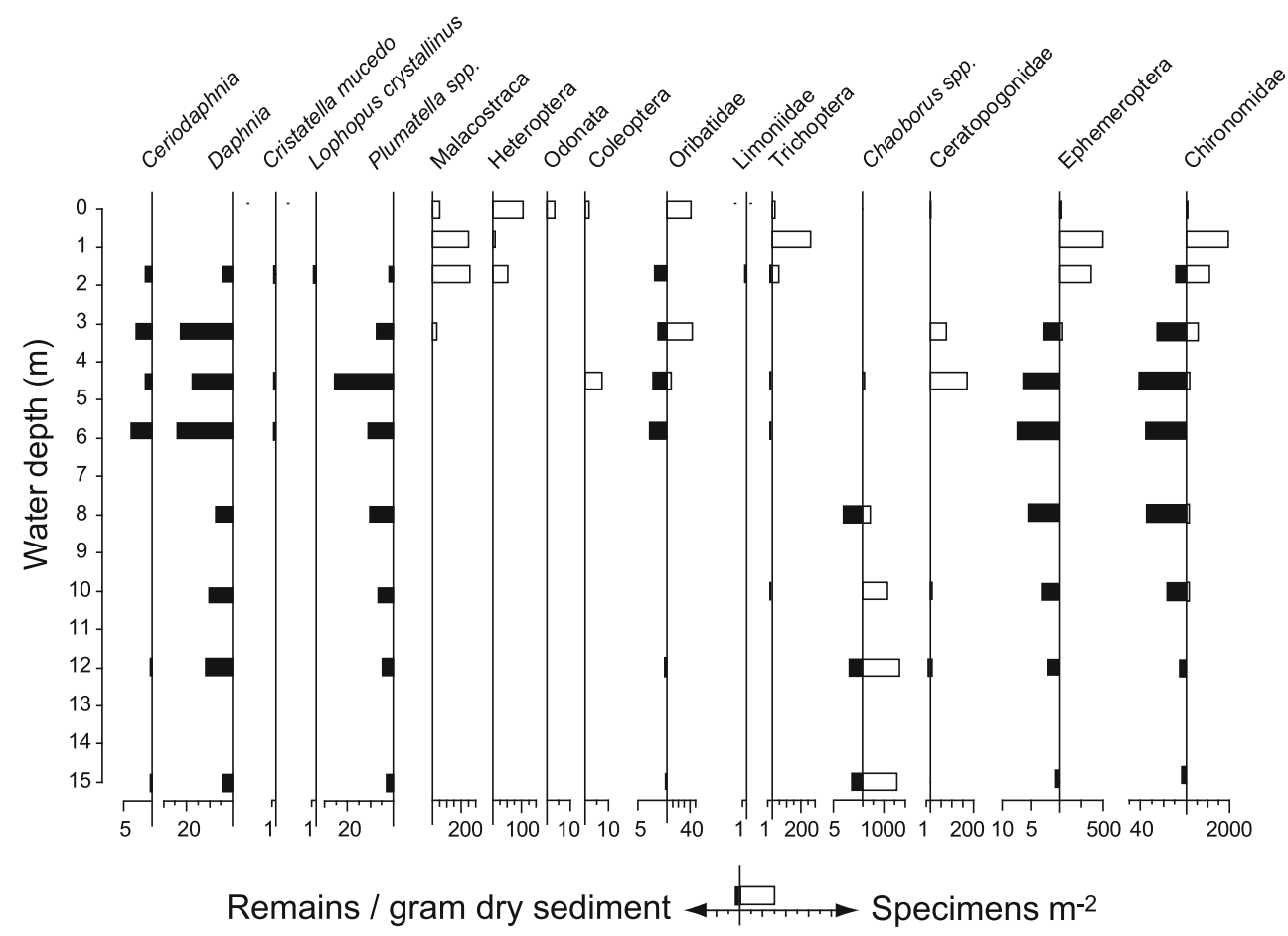

Fig. 6 DCA plot based on living and subfossil assemblages from different water depths in Lake De Waay. a Samples of living assemblages (open circles) and subfossil assemblages (grey circles) with their respective depth indicated. b Invertebrate taxa occurring in both living and subfossil assemblages

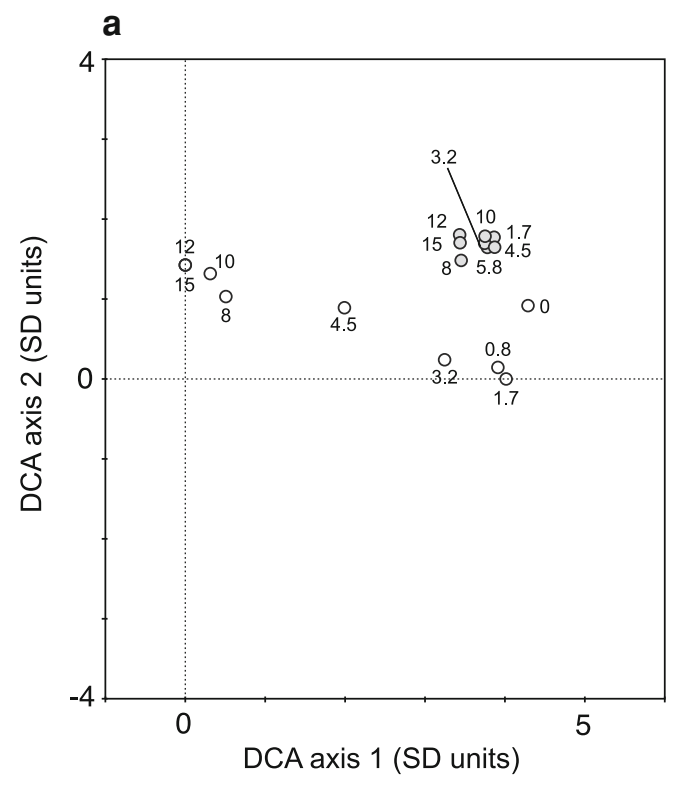

b

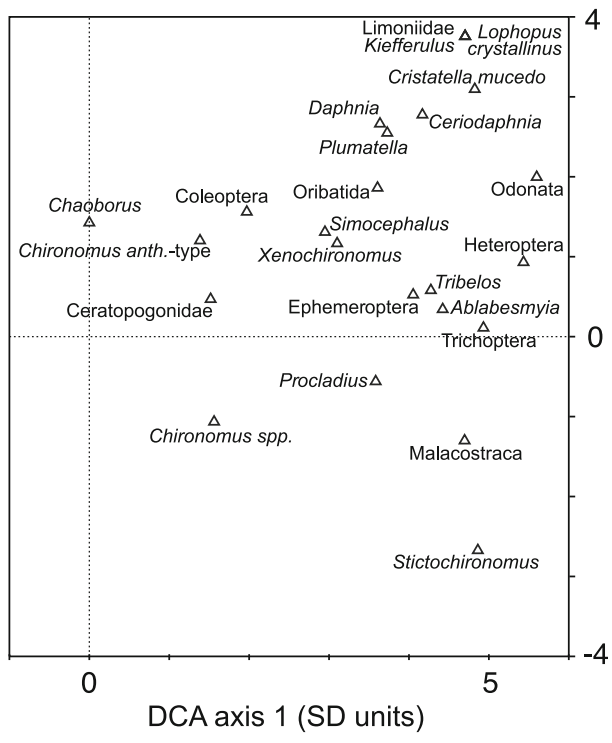

samples should provide representative counts and include the most dominant chironomid taxa (Heiri and Lotter 2001; Quinlan and Smol 2001b).

Several genera that were encountered only in subfossil assemblages such as Corynoneura, Dicrotendipes, Endochironomus, and Metriocnemus are often associated with macrophytes (Pinder and Reiss 1983; Brodin 1986; Brodersen et al. 2001; Merritt et al. 2008; Moller Pillot 2009). Other groups, such as Bryozoa, are associated with woody substrates or aquatic macrophytes (Wood and Okamura 2005) and Xenochironomus xenolabis is known to be a parasite on Spongillidae (Pinder and Reiss 1983; Moog 2002). More extensive sampling for living invertebrates on specific substrates could have added some of these taxa to the living assemblages. Similarly, certain taxa may not have been sampled because sampling of living invertebrates took place on only three dates. The timing of these sampling days allowed us to collect specimens at different moments in the seasonal cycle, but ideally, the living assemblages should have been sampled more often to obtain a more complete overview. 
Fig. 7 Comparison between densities of six chironomid taxa and their remains in Lake De Waay at different water depths. The values for living larvae are averages of three sampling campaigns on 13 September 2007, 22 April 2008, 17 February 2009

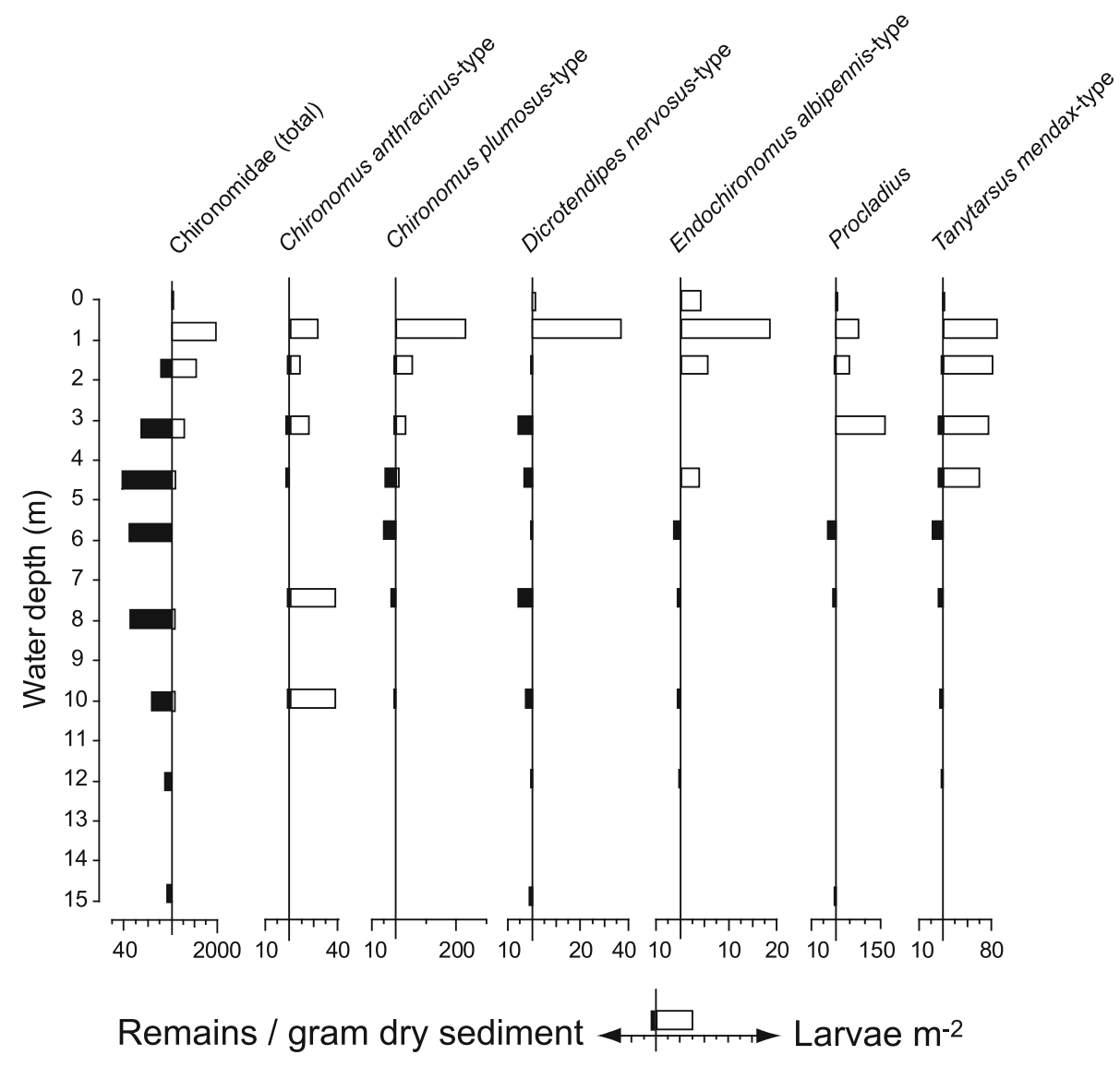

A reason for the absence of some invertebrate groups (Coleoptera, Heteroptera, Malacostraca, Odonata) in the subfossil assemblages might be the lack of keys for the identification of characteristic remains. This is also the reason for the loss of taxonomic detail for Ephemeroptera, Oribatida, and Trichoptera. However, detailed keys are available for chironomid remains and in this group similar taxa are encountered in living and subfossil assemblages, although the taxonomic detail was greater in living assemblages (Table 2). The majority of chironomid taxa occurred in both living and subfossil assemblages. In living assemblages, only five rare taxa were found of which no remains were encountered. However, eight rare and four common chironomid taxa in the subfossil assemblage were not found in the living assemblage. This suggests that in Lake De Waay the palaeolimnological approach provided a more complete overview of chironomid taxa than the sampling of living larvae during three seasons.

Distribution of taxa along depth transect

The only taxa found in living assemblages in the deepest part of the lake were larvae of Ceratopogonidae, Chironomus annularius, and Chaoborus flavicans (Figs. 3, 5). The latter two of these taxa are exceptionally well adapted for surviving at low oxygen levels in the hypolimnion (Hofmann 1986; Jager and Walz 2002; Luoto and Nevalainen 2009). Oxygen availability is one of the key factors for the distribution of invertebrates in stratified lakes (Pinder 1995; Jager and Walz 2002). In Lake De Waay, oxygen levels decrease with depth (Fig. 2) and during summer stratification the profundal is anoxic. Therefore, changes in the invertebrate community with water depth, indicated by the position of samples along DCA axis 1 (Fig. 6), are likely to be related to oxygen availability. The living assemblages in shallow water samples $(\leq 3.2 \mathrm{~m}$ water depth) are distinctly different from the living assemblages in deep water samples ( $\geq 8 \mathrm{~m}$ water depth), and it is interesting to note the sample at $4.5 \mathrm{~m}$ water depth, located approximately at the thermocline, fell in between. These findings are in line with several studies that have indicated the potential to use subfossil chironomid assemblages to infer hypolimnetic oxygen levels (Quinlan and Smol 2001a; Brodersen and Quinlan 2006).

Water temperature may also have affected the in-lake distribution of invertebrates. In dimictic lakes, such as Lake De Waay, water temperatures show large annual variations in the littoral and sublittoral of the lake basin, whereas the deeper section of the basin will remain cool during the summer months (in De Waay typically not 
exceeding $8^{\circ} \mathrm{C}$ ). A number of invertebrate taxa are known to be restricted to low temperatures during their larval development and their larvae are limited to the cool hypolimnion during the summer months, whereas other taxa are dependent on warmer temperature to complete their development (Brinkhurst 1974; Pinder 1995; de Mendoza and Catalan 2010).

Substrate composition also has a strong influence on chironomid distribution (Pinder 1986; de Mendoza and Catalan 2010) and changed within Lake De Waay from the shore towards the lake centre. In the deepest section of the lake, the only substrate available for benthic invertebrates consists of soft organic mud. In shallower sections of the lake, particle size of the sediments becomes coarser and habitats are supplemented by macrophytes, leaf litter, and dead wood. Several authors observed that locations with macrophytes generally have a greater complexity of habitats available for aquatic invertebrates as well as more diverse subfossil assemblages than macrophyte-free areas (Pinder 1995; Eggermont et al. 2007, 2008; de Mendoza and Catalan 2010). Macrophytes are an important food source and provide habitats for many taxa, and may also provide shelter or escape from predation (Merritt et al. 2008). Eggermont et al. (2008) investigated a depth transect in Lake Tanganyika, East Africa, and observed the highest densities of living chironomid larvae at 3-5 m depth at locations with macrophytes. Rumes (2010) collected both living invertebrates and their remains in 61 African crater lakes and observed that a significant part of the variation in living and subfossil assemblages was explained by the diversity of macrophytes. Several groups of aquatic insects and Plumatella were found clinging to or living between submerged or emerging macrophytes (Rumes 2010). Although we did not extensively sample macrophytes for living invertebrates, we did observe high invertebrate diversity and abundances in the sediment samples from the macrophyte zone $(0-1.7 \mathrm{~m})$ in Lake De Waay.

Taphonomy of invertebrate remains

The distribution of subfossil assemblages along the sampling transect in Lake De Waay was distinctly different from the distribution of the living invertebrates from which the remains originate. For the majority of taxa, the subfossil remains had a remarkably homogeneous distribution compared to living assemblages. This is demonstrated in the DCA plot, in which samples of living assemblages are distributed according to water depth along axis 1 (Fig. 6), whereas samples of subfossil assemblages plot together. The subfossil assemblages in Lake De Waay are most similar to the living invertebrate community in the littoral zone, between 0.8 and $3.2 \mathrm{~m}$ water depth. Similar results were found by Brodersen and Lindegaard (1999) who observed that the subfossil assemblages sampled in the lake centre reflected the chironomid communities in the littoral at a depth of 2-7 $\mathrm{m}$ in four Danish lakes.

The discrepancy between living and subfossil assemblages (Figs. 5, 7) could be partly explained by the limited temporal and spatial sampling of living invertebrates as indicated above. However, this cannot explain the high number of subfossil remains of littoral taxa in the profundal of Lake De Waay, which can be explained (at least in part) by transportation of subfossils (Frey 1988). Physical lake characteristics such as lake surface area, volume, morphometry, and sediment type determine the influence of in-lake currents and, hence, can have a large influence on the amount of transport of chitinous remains that occurs (Hilton 1985; Frey 1988). Redistribution of littoral remains off-shore depends strongly on basin morphometry (Frey 1988; Eggermont et al. 2007). In our dataset, we have only found evidence for off-shore displacement of remains from the location at which the corresponding living organisms were found, and never in a shoreward direction. For example, living larvae of Dicrotendipes nervosus-type, Endochironomus albipennis-type, Ephemeroptera, and Oribatida were found only in samples from $\leq 4.5 \mathrm{~m}$ water depth. However, their remains were abundant in profundal sediments (Figs. 5, 7). The steep basin morphology of Lake De Waay may be an important factor in explaining the transportation of invertebrate remains as sediment focusing is more pronounced in basins with steep slopes (Kansanen 1986).

Overall, this is in agreement with the results of previous studies that found evidence for off-shore transport of invertebrate remains. Evidence for transport of chironomid remains to deeper sections of lakes was observed in shallow and continually mixing lakes (Iovino 1975; Hofmann 1986; Eggermont et al. 2007; Holmes et al. 2009) as well as in deeper, stratifying lakes (Wiederholm 1979; Schmäh 1993; Brodersen and Lindegaard 1999; Heiri 2004). In a survey of African crater lakes, more invertebrate taxa were recovered as subfossil remains from surface sediments than by collecting living invertebrates (Rumes et al. 2005; Rumes 2010), which may also be the result of the limited spatial and temporal sampling of living invertebrates. It is unlikely, however, that transport of remains can cause a complete integration of littoral and profundal communities (Frey 1988; Heiri 2004). Moreover, transport of remains does not play an important role in all lakes (Iovino 1975; Walker et al. 1984; Kurek and Cwynar 2009b; Luoto 2010). The most detailed study previously available that compared living and subfossil assemblages of chironomids by Iovino (1975) demonstrated that communities and their remains were qualitatively and quantitatively similar in a number of lakes. In the lakes studied in his survey, the ratio 
between the mean number of larvae $\mathrm{m}^{-2}$ and the number of remains per $100 \mathrm{ml}$ surficial sediment was approximately 0.1 , although higher ratios were also observed. However, in lakes that are prone to wind-driven currents, Iovino (1975) observed transportation of subfossil remains from typical littoral taxa to the sublittoral and from sublittoral taxa to the profundal. The importance of wind for transport of remains is also recognized by others (Schmäh 1993; Eggermont et al. 2007; Holmes et al. 2009). Similarly, currents by inflowing streams can transport lotic and littoral remains into deeper parts of the basin (Heiri 2004; Bigler et al. 2006; Heiri and Lotter 2007; Luoto 2010).

The highest concentrations of living invertebrates in Lake De Waay were observed at 0-3.2 $\mathrm{m}$ water depth, whereas the highest concentrations of subfossil remains were observed at $4.5 \mathrm{~m}$ water depth in the sublittoral. This pattern may be explained by different sedimentation rates within the basin and, possibly, by the location of the thermocline around $5 \mathrm{~m}$ water depth in Lake De Waay. Iovino (1975) observed a similar pattern that was most clear in transects influenced by wind-generated currents. Wind and wave action will be weaker below the thermocline and a relatively large number of subfossil remains could be expected to be redeposited at the thermocline. Schmäh (1993) also observed a peak in concentrations of chironomid subfossils in the sublittoral zone of Lake Constance. This peak occurred at a depth of approximately 4-11 m. It is unclear, however, whether this coincided with the depth of the thermocline during stratification or with the depth at which the slope of the lake bottom became steeper. There was no indication of a thermocline effect on the concentrations of chironomid remains studied by Heiri (2004). Highest subfossil concentrations were found in the profundal of four of the five relatively shallow Norwegian lakes that he studied. Only one dystrophic lake with low oxygen conditions in the hypolimnion had highest concentrations at the thermocline depth in the sublittoral, but this was likely due to limited production of chironomid remains in the profundal. Kurek and Cwynar (2009b) sampled chironomid remains at different water depths in three lakes in western Alaska that have a comparable bathymetry to Lake De Waay. Only in one of these three lakes did they observe a significant change in the composition of chironomid assemblages at the depth of the thermocline.

\section{Conclusions}

The overall taxonomic composition of living and subfossil invertebrate assemblages in Lake De Waay was similar, at least for chironomids that could be identified at a comparable taxonomic level in living and subfossil assemblages.
A total of 44 chironomid taxa were found in Lake De Waay, of which 30 taxa occurred in both living and subfossil assemblages. These 30 taxa included, on average, $94 \%$ of the specimens in the studied samples. This demonstrates that biomonitoring approaches based on benthic samples containing living chironomids and palaeolimnological approaches examining subfossil chironomid remains in lake surface sediments will give comparable assemblage compositions. In contrast to samples of living assemblages, surface sediments analyzed for invertebrate remains also represent the invertebrate fauna occurring in the lake over a period of seasons to years and in a range of (micro)habitats. However, systematic identification keys for subfossil remains of several non-chironomid groups are still urgently required to allow identification of subfossil assemblages at a comparable taxonomic level for all invertebrate groups.

We observed a distinct difference in distribution between living invertebrate larvae and subfossil remains within the basin of Lake De Waay. Living invertebrates were mostly constrained to the littoral and sublittoral zone with the exception of a few taxa (Chaoborus flavicans and Chironomus) that are adapted to low oxygen conditions in the profundal of this eutrophic lake. Our results suggest that remains are transported and redeposited off-shore in Lake De Waay due to its steep bathymetry. A single sediment sample obtained from the centre of this lake contained subfossil invertebrate remains originating from the entire lake basin. In contrast to Luoto (2010), our results support previous observations indicating that, in palaeolimnological studies, one profundal core can provide an integrated assessment of benthic invertebrate remains originating from the entire lake basin, especially in relatively small lakes with a steep bathymetry. Examining both living and subfossil assemblages will provide more complete and detailed information about the invertebrate community in a lake ecosystem than examination of only one of these assemblages.

Acknowledgments We thank Emiliya Kirilova, Tjeerd du Bois, Saskia Kuiper and Alejandra Goldenberg for field assistance and Ton van Haaren, Amy Storm, Lidewij Servatius, David Tempelman and Bert Storm for identifying living invertebrates in the samples. Jack Middelburg and Marco Houtekamer (NIOO-KNAW Yrseke) as well as Peter Spierenburg and Jelle Eygensteyn (Radboud University Nijmegen) are kindly acknowledged for water chemistry analysis, and Joshua Kurek and two anonymous reviewers for helpful comments and suggestions on the manuscript. This is publication number DW2010-1012 of the Darwin Center for Biogeosciences, which financially supported this study. This is Netherlands Research School of Sedimentary Geology publication no. 20101003.

Open Access This article is distributed under the terms of the Creative Commons Attribution Noncommercial License which permits any noncommercial use, distribution, and reproduction in any medium, provided the original author(s) and source are credited. 


\section{References}

Bigler C, Heiri O, Krskova R, Lotter AF, Sturm M (2006) Distribution of diatoms, chironomids and cladocera in surface sediments of thirty mountain lakes in south-eastern Switzerland. Aquat Sci 68:154-171

Brinkhurst RO (1974) The benthos of lakes. MacMillan Press, London

Brodersen KP, Lindegaard C (1999) Classification, assessment and trophic reconstruction of Danish lakes using chironomids. Freshwater Biol 42:143-157

Brodersen KP, Quinlan R (2006) Midges as palaeoindicators of lake productivity, eutrophication and hypolimnetic oxygen. Quaternart Sci Rev 25:1995-2012

Brodersen KP, Odgaard BV, Vestergaard O, Anderson NJ (2001) Chironomid stratigraphy in the shallow and eutrophic Lake Søbygaard, Denmark: chironomid-macrophyte co-occurrence. Freshwater Biol 46:253-267

Brodin YW (1986) The postglacial history of Lake Flarken, southern Sweden, interpreted from subfossil insect remains. Int Rev Ges Hydrobiol 71:371-432

Brooks SJ, Langdon PG, Heiri O (2007) The identification and use of Palaearctic Chironomidae larvae in palaeoecology. QRA technical guide no. 10. Quaternary Research Association, London

Clarke KR, Warwick RM (2001) Change in marine communities: an approach to statistical analysis and interpretation. Primer-E Ltd, Plymouth

de Mendoza G, Catalan J (2010) Lake macroinvertebrates and the altitudinal environmental gradient in the Pyrenees. Hydrobiologia 648:51-72

Eggermont H, De Deyne P, Verschuren D (2007) Spatial variability of chironomid death assemblages in the surface sediments of a fluctuating tropical lake (Lake Naivasha, Kenya). J Paleolimnol 38:309-328

Eggermont H, Kennedy D, Hasiotis ST, Verschuren D, Cohen A (2008) Distribution of living larval Chironomidae (Insecta: Diptera) along a depth transect at Kigoma Bay, Lake Tanganyika: implications for palaeoenvironmental reconstruction. Afr Entomol 16:162-184

Free G, Solimini A, Rossaro B, Marziali L, Giacchini R, Paracchini B, Ghiani M, Vaccaro S, Gawlik B, Fresner R, Santner G, Schönhuber M, Cardoso A (2009) Modelling lake macroinvertebrate species in the shallow sublittoral: relative roles of habitat, lake morphology, aquatic chemistry and sediment composition. Hydrobiologia 633:123-136

Frey DG (1964) Remains of animals in Quaternary lake and bog sediments and their interpretation. Arch Hydrobiol 2:1-114

Frey DG (1988) Littoral and offshore communities of diatoms, cladocerans and dipterous larvae, and their interpretation in paleolimnology. J Paleolimnol 1:179-191

Grontmij (2010) SOP A-207 analysis procedure for processing and identification of macrofauna. Internal analysis procedure (in Dutch)

Heiri O (2004) Within-lake variability of subfossil chironomid assemblages in shallow Norwegian lakes. J Paleolimnol 32:67-84

Heiri O, Lotter A (2001) Effect of low count sums on quantitative environmental reconstructions: an example using subfossil chironomids. J Paleolimnology 26:343-350

Heiri O, Lotter AF (2003) 9,000 years of chironomid assemblage dynamics in an Alpine lake: long-term trends, sensitivity to disturbance, and resilience of the fauna. J Paleolimnol 30:273-289

Heiri O, Lotter A (2007) Sciaridae in lake sediments: indicators of catchment and stream contribution to fossil insect assemblages. J Paleolimnol 38:183-189
Heiri O, Cremer H, Engels S, Hoek WZ, Peeters W, Lotter AF (2007) Lateglacial summer temperatures in the Northwest European lowlands: a chironomid record from Hijkermeer, the Netherlands. Quaternary Sci Rev 26:2420-2437

Hilton J (1985) A conceptual framework for predicting the occurrence of sediment focusing and sediment redistribution in small lakes. Limnol Oceanogr 30:1131-1143

Hofmann W (1986) Analyse tierischer Mikrofossilien in Seesedimenten: langfristige Veränderungen der limnischen Fauna im Zusammenhang mit der Entwicklung ihres Lebensraums. Habilitationsschrift. Christian-Albrechts-Universität Kiel, Plön

Hofmann W (1988) The significance of chironomid analysis (Insecta: Diptera) for paleolimnological research. Palaeogeogr Palaeocl 62:501-509

Holmes N, Langdon P, Caseldine C (2009) Subfossil chironomid variability in surface sediment samples from Icelandic lakes: implications for the development and use of training sets. J Paleolimnol 42:281-295

Ilyashuk B, Gobet E, Heiri O, Lotter AF, van Leeuwen JFN, van der Knaap WO, Ilyashuk E, Oberli F, Ammann B (2009) Lateglacial environmental and climatic changes at the Maloja Pass, Central Swiss Alps, as recorded by chironomids and pollen. Quaternary Sci Rev 28:1340-1353

Iovino AJ (1975) Extant chironomid larval populations and the representativeness and nature of their remains in lake sediments. $\mathrm{PhD}$ thesis. Indiana University

Jager IS, Walz N (2002) Chaoborus flavicans (Diptera) is an oxyregulator. Arch Hydrobiol 155:401-411

Kansanen PH (1986) Information value of chironomid remains in the uppermost sediment layers of a complex lake basin. Hydrobiologia 143:159-165

Kattel G, Battarbee R, Mackay A, Birks H (2007) Are cladoceran fossils in lake sediment samples a biased reflection of the communities from which they are derived? J Paleolimnol 38:157-181

Kirilova E, van Hardenbroek M, Heiri O, Cremer H, Lotter AF (2010) 500 years of eutrophication history of a hypertrophic Dutch dike-breach lake. J Paleolimnol 43:829-842

Korhola A, Olander H, Blom T (2000) Cladoceran and chironomid assemblages as quantitative indicators of water depth in subarctic Fennoscandian lakes. J Paleolimnol 24:43-54

Kurek J, Cwynar L (2009a) Effects of within-lake gradients on the distribution of fossil chironomids from maar lakes in western Alaska: implications for environmental reconstructions. Hydrobiologia 623:37-52

Kurek J, Cwynar L (2009b) The potential of site-specific and local chironomid-based inference models for reconstructing past lake levels. J Paleolimnol 42:37-50

Langdon PG, Ruiz ZOE, Brodersen KP, Foster IDL (2006) Assessing lake eutrophication using chironomids: understanding the nature of community response in different lake types. Freshwater Biol 51:562-577

Leentvaar P (1958) Observations on the plankton of some inland waters, especially 'wielen', in the Netherlands. Beaufortia, Series of Miscellaneous Publications 73:171-197

Lotter AF, Birks HJB, Hofmann W, Marchetto A (1998) Modern diatom, cladocera, chironomid, and chrysophyte cyst assemblages as quantitative indicators for the reconstruction of past environmental conditions in the Alps. II. Nutrients. J Paleolimnol $19: 443-463$

Luoto TP (2010) Hydrological change in lakes infrerred from midge assemblages through use of an intralake calibration set. Ecol Monogr 80:303-329

Luoto TP, Nevalainen L (2009) Larval chaoborid mandibles in surface sediments of small shallow lakes in Finland: implications for palaeolimnology. Hydrobiologia 631:185-195 
Merritt RW, Cummins KW, Berg MB (2008) An introduction to the aquatic insects of North America, Kendall and Hunt, Dubuque

Moller Pillot HKM (2009) Chironomidae Larvae, biology and ecology of the Chironomini. KNNV Publishing, Zeist

Moog O (2002) Fauna Aquatica Austriaca. Wasserwirtshcaftskataster, Bundesministerium für Land- und Forstwirtschaft, Umwelt und Wasserwirtschaft, Vienna

Pinder LCV (1986) Biology of freshwater chironomidae. Annu Rev Entomol 31:1-23

Pinder LCV (1995) The habitats of chironomid larvae. In: Armitage PD, Cranston PS, Pinder LCV (eds) The chironomidae: the biology and ecology of non-biting midges. Chapman and Hall, London, pp 107-135

Pinder LCV, Reiss F (1983) The larvae of Chironominae (Diptera: Chironomidae) of the Holarctic region. Keys and diagnoses. Entomol Scand Suppl 19:293-435

Quinlan R, Smol JP (2001a) Chironomid-based inference models for estimating end-of-summer hypolimnetic oxygen from southcentral Ontario shield lakes. Freshwater Biol 46:1529-1551

Quinlan R, Smol JP (2001b) Setting minimum head capsule abundance and taxa deletion criteria in chironomid-based inference models. J Paleolimnol 26:327-342

Quinlan R, Smol JP (2010) The extant Chaoborus assemblage can be assessed using subfossil mandibles. Freshwater Biol. doi: $10.1111 /$ j.1365-2427.2010.02476.x

Renberg I, Hansson H (2008) The HTH sediment corer. J Paleolimnol 40:655-659

Reusch H, Oosterbroek P (1997) Diptera Limoniidae and Pediciidae, Short-Palped Crane Flies. In: Nilsson AN (ed) Aquatic insects of northern Europe-a taxonomic handbook, vol 2. Apollo Books, Stenstrup, pp 107-132

Rieradevall M, Brooks SJ (2001) An identification guide to subfossil Tanypodinae larvae (Insecta: Diptera: Chironomidae) based on cephalic setation. J Paleolimnol 25:81-99

Rosenberg DM, Resh VH (1993) Freshwater biomonitoring and benthic macroinvertebrates. Chapman and Hall, New York

Rumes B (2010) Regional diversity, ecology and palaeoecology of aquatic invertebrate communities in East African lakes. $\mathrm{PhD}$ thesis. Ghent University
Rumes B, Eggermont H, Verschuren D (2005) Representation of aquatic invertebrate communities in subfossil death assemblages sampled along a salinity gradient of western Uganda crater lakes. Hydrobiologia 542:297-314

Sayer CD, Davidson TA, Jones JI, Langdon PG (2010) Combining contemporary ecology and palaeolimnology to understand shallow lake ecosystem change. Freshwater Biol 55:487-499

Schmäh A (1993) Variation among fossil chironomid assemblages in surficial sediments of Bodensee-Untersee (SW-Germany): implications for paleolimnological interpretation. J Paleolimnol 9:99-108

Smol JP (2008) Pollution of lakes and rivers: a paleoenvironmental perspective, 2nd edn. Wiley, Oxford

Smol JP, Birks HJB, Last W (2001) Tracking environmental change using lake sediments. Volume 4: zoological indicators. Kluwer, Dordrecht

ter Braak CJF, Šmilauer P (2003) Program CANOCO, version 4.52. Biometris-quantitative methods in the life and earth sciences. In: Plant research international, Wageningen University and Research Centre, Wageningen

Vanderkerkhove J, Declerck S, Vanhove M, Brendonck L, Jeppesen E, Porcuna JM, De Meester L (2004) Use of ephippial morphology to assess richness of anomopods: potentials and pitfalls. J Limnol 63:75-84

Verbruggen F, Heiri O, Lotter AF (2010) Subfossil chironomid assemblages in deep, stratified European lakes: relation with temperature, trophic state and oxygen. Freshwater Biol. doi: 10.1111/j.1365-2427.2010.02508.x

Walker I, Fernando CH, Paterson CG (1984) The chironomid fauna of four shallow, humic lakes and their representation by subfossil assemblages in the surficial sediments. Hydrobiologia 112:61-67

Wiederholm T (1979) Chironomid remains in recent sediments of Lake Washington. Northwest Sci 53:251-256

Wiederholm T (1983) Chironomidae of the Holarctic region. Keys and diagnoses. Part. 1. Larvae. Entomol Scand Suppl 19:1-457

Wood TS, Okamura B (2005) A new key to freshwater bryozoans of Britain, Ireland and continental Europe, with notes on their ecology. Freshwater Biological Association, London 